\title{
Richness and abundance of caterpillars on Byrsonima (Malpighiaceae) species in an area of cerrado vegetation in Central Brazil
}

\author{
Isabel Andrade ${ }^{1,3}$, Helena C. Morais ${ }^{1}$, Ivone R. Diniz ${ }^{2}$ and Cássio van den Berg ${ }^{3}$ \\ 1 Departamento de Ecologia, Universidade de Brasilía, Brasilia, DF, Brazil. E-mail:morais@unb.br \\ 2 Departamento de Zoologia, Universidade de Brasília, Brasília, DF, Brazil. Fax (061)2741141. \\ E-mail:ivone@rudah.com.br \\ 3 Pós-Graduação em Ecologia, Universidade Estadual de Campinas, Campinas, SP, Brazil.
}

Received 21-VI-1999. Corrected 2-VII-1999. Accepted 7-VII-1999

\begin{abstract}
We sampled lepidopteran caterpillars on three Byrsonima species (Malpighiaceae) in Central Brazil: Byrsonima crassa, Byrsonima verbascifolia and Byrsonima coccolobifolia between May 1993 and July 1994. Fifteen individuals of each plant species were censused weekly. Our main goal was to estimate the abundance and richness of lepidopteran larvae within each plant species. Only $13 \%$ of the 1621 sampled plants had caterpillars on their leaves. This percentage was similar within each plant species. We found a pattern of low abundance and high richness of lepidopteran species associated with Byrsonima. There were 48 morphospecies and $46 \%$ of them occurred just once. There was a higher similarity between the fauna of $B$. crassa and $B$. verbascifolia than between these and $B$. coccolobifolia. Once it is known that hairy leaves can affect herbivore colonization and foraging strategy, we suggest that differences in the lepidopteran community associated with Byrsonima spp. are linked with different levels of pubescence on the leaf surface of each plant species. This tendency in Byrsonima is supported by the small number of caterpillars found on young leaves of $B$. crassa and $B$. verbascifolia, which are quite hairy.
\end{abstract}

Key words: Insect herbivory, Byrsonima, Lepidoptera, richness, community structure, plant defenses, cerrado vegetation.

The distribution and abundance of species in nature are determined by factors such as natural enemies, competitors and resources. Recently, many ecologists have embraced a view that patterns of diversity are caused by a variety of ecological and evolutionary processes, historical events, and geographical circumstances (Schluter and Ricklefs 1993). However, there is a lack of baseline data such as species lists, guild structure and morphological diversity that would allow researchers to relate species richness to the occupation and utilization of ecological resources.

For instance, the knowledge of the composition of a herbivore fauna for individual plant species allows us to distinguish the importance of morphological and phenological plant traits on its associated fauna. However, information on the species richness of phytophagous insects associated with different plant species is often obtained from literature food-plant lists and it has been suggested that this method can produce biased data (Fielding and Coulson 1995, but see Southwood et al. 1982).

The empirical basis for our present understanding of plant-herbivore interactions comes largely from studies in temperate regions. Few works depicting the fauna associated with particular plant species have been published in the tropics (e.g., Lewinsohn 1991, Marquis 1991, 
Loyola and Fernandes 1993, Marquis and Braker 1994, Price et al. 1995, Diniz and Morais 1997). Indeed a major part of the hostplants used by lepidopteran caterpillars is still unknown (De Vries 1987).

We carried out a quantitative survey of lepidopteran caterpillars associated with three species of Byrsonima (Malpighiaceae) in Central Brazil. Our main goal was to estimate the abundance and richness of lepidopteran larvae within each plant species and to relate them to the morphological traits and abundance of the plants. We have chosen caterpillars for their slow-moving habits, and because local expertise provided a much higher probability of identifying insect species than for other herbivore taxa.

\section{METHODS}

We conducted the study at the University of Brasília Experimental Farm (Fazenda Água Limpa, 15⒌', $47^{\circ} 55^{\prime} \mathrm{W}$ ) between May 1993 and July 1994 . The area is covered by cerrado sensu stricto, a savanna-like vegetation. Central Brazil has a sharp seasonal climate of five dry months, from May to September.

Byrsonima crassa Nied, Byrsonima verbascifolia L. Rich and Byrsonima coccolobifolia (Spr.) Kunth are shrubs or small trees (0.5$4.5 \mathrm{~m}$ tall). While B. crassa and B. verbascifolia have tough, hairy leaves, $B$. coccolobifolia has smooth, glabrous leaves. The plants are deciduous and change their leaves during the dry season (Morais et al. 1995). The number of individual plants counted in 0.25 ha was as follows: $B$. crassa $37, B$. verbascifolia 15 , and $B$. coccolobifolia 16. Despite this, in a regional distribution sense, $B$. crassa has the smallest geographical range (Ratter and Dargie 1992).

We sampled lepidopteran larvae weekly, searching on the old and the new foliage of 15 individuals of each Byrsonima species( $\leq 2.5$ $\mathrm{m}$ tall). The study area was located within a 1 ha block divided into quarters, with one quadrate used at one sampling time. Subsequent samples used the other quarter in rotation. We collected the larvae, established morphospecies and reared them in the laboratory. Adults were sent to specialists for identification.

We performed multivariate analysis on caterpillar abundance data to extract the relationship between the host-plant species and its associated fauna. At first, we did a cluster analysis on non-standardized data and constructed a dendrogram with the Byrsonima species. Then we proceeded to a Principal Component Analysis (PCA) based on covariance square matrix to identify the general pattern of association of caterpillars with plant species. Through the use of non-standardized data and covariance matrix each species have a weight in the analysis proportional to its abundance-rarity.

\section{RESULTS}

Only $13 \%$ of the 1,621 sampled plants had caterpillars on their leaves. This percentage was similar within each plant species (Table 1).

There were 48 morphospecies and $46 \%$ of them occurred just once. Only six species of lepidopteran larvae were collected more than 15 times: Cerconota achatina Zeller (109 times), Gonioterma indecora Zeller (50), Gonioterma exquisita Duckworth (35) and Timocratica melanocosta Becker (24) (Oecophoridae), Chiomara punctum Mabille (16) (Hesperiidae), and Anacampsis sp. (16) (Gelechiidae). Also, the accumulation of new lepidopteran species with the increase number of plants sampled showed positive, non-asymptotic curves indicating that additional sampling would continue to yield new species (Fig. 1).

There was a higher similarity between the fauna of $B$. crassa and $B$. verbascifolia than between these and B. coccolobifolia (Fig. 2). The PCA biplot (Fig. 3) explains the similarity pattern found: The first axis ( $84.29 \%$ of the variance) contrasts $B$. coccolobifolia against $B$. cras$s a$ and $B$. verbascifolia. The second axis ( $15.71 \%$ of the variance) shows $G$. indecora associated with $B$. crassa and the exclusive Anacampsis sp. associated with $B$. verbascifolia. 


\section{TABLE 1}

Total number of Byrsonima sampled plants, number of plants with caterpillars, and species richness within each plant species between May 1993 and July 1995 at the University of Brasilia Experimental Farm, Brazil

Host plant species

Number of plants sampled

\section{Byrsonima crassa}

Byrsonima

verbascifolia

Byrsonima

coccolobifolia

Total
573

534

514

1,621
$\%$ of plants with caterpillars

12.7

11.6

14.9

13.0
Lepidopteran species richness

24

21

23

48

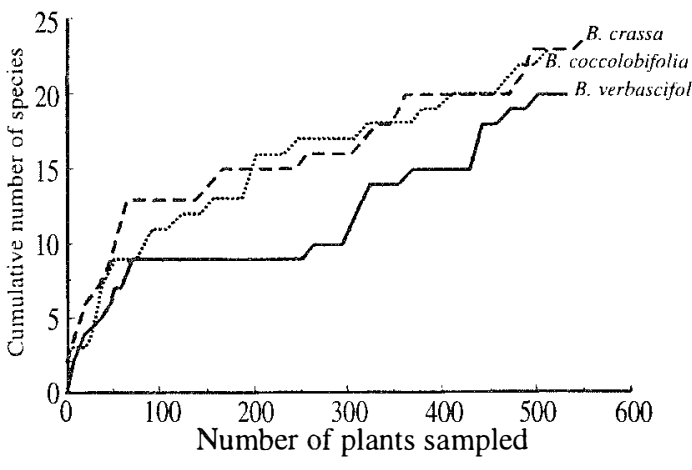

Fig. 1. Cumulative number of caterpillar species recorded with increasing number of the three Byrsonima species sampled.

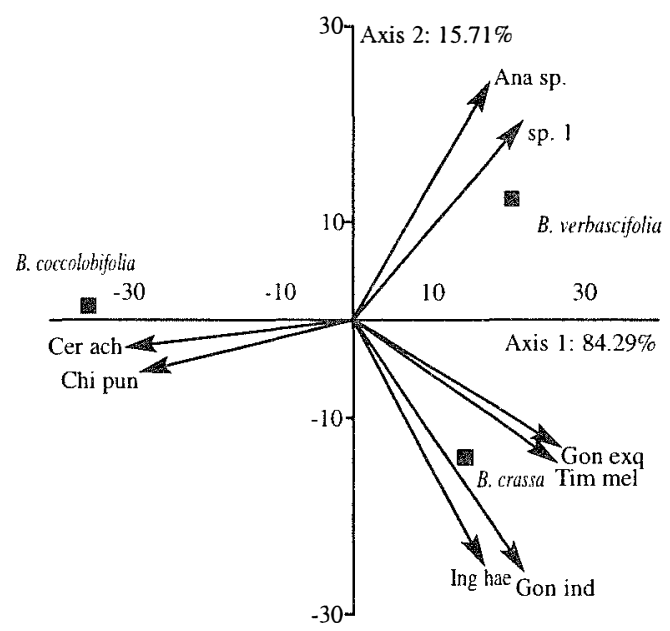

Fig. 3. Scores and autovectors of three species of Byrsonima in the first two axis of a Principal Component Analysis (PCA). Autovectors lower than 0.1 were not plotted. Cer ach = Cerconota achatina, Gon exq = Gonioterma exquisita, Tim mel $=$ Timocratica melanocosta, Gon ind = Gonioterma indecora, Chi pun = Chiomara punctum, Ana sp. = Anacampsis sp., sp. 1 = unidentified species.
Euclidean Distance

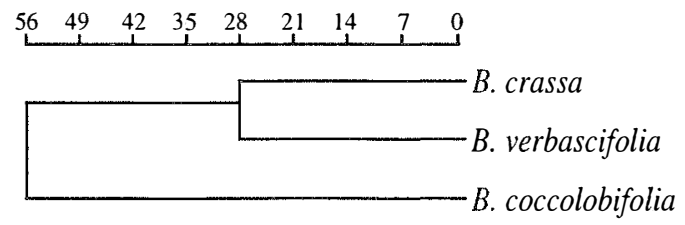

Fig. 2. UPGMA clustering of three Byrsonima species upon the lepidopteran larvae species richness and abundance between May 1993 and July 1994 at the University of Brasília Experimental Farm, Brazil.

\section{DISCUSSION}

We found a pattern of low abundance and high richness of lepidopteran larvae associated with Byrsonima. Price et al. (1995) found a similar pattern for Erythroxylum (Erythroxylaceae) species in the same study area. Moreover, lepidopteran species richness within each individual Byrsonima species was notably high (Table 1) considering the size of the study area and the sampling time. For instance, Janzen's (1988) unique data set for the Lepidoptera in a tropical locality (Santa Rosa National Park, Costa Rica) reported no more than 20 species per host plant after six years of exhaustive sampling.

Some studies have shown a relationship between local and geographical abundance of plant hosts and richness of the herbivore fauna (Neuvonen and Niemelä 1981, Lawton 1982, Leather 1986, Marquis 1991). The richness of Byrsonima's lepidopteran fauna was similar for the three plant species despite their regional and local abundance. However, the range of 
local abundance among the three Byrsonima species is only about two-fold. For instance, in the study done by Neuvonen and Niemelä (1981) the host's local frequency varied from 0.3 to 39 (over 100-fold variation).

As the three plant species have a large number of exclusive and rare caterpillar species [B. crassa (9 species), B. verbascifolia (9), and B. coccolobifolia (13)], the higher similarity between the fauna of $B$. crassa and $B$. verbascifolia than between these and $B$. coccolobifolia (Fig. 2) may be explained by the occurrence of the most abundant species.

The PCA biplot (Fig. 3) explains the similarity pattern found. The difference contrasting $B$. coccolobifolia against $B$. crassa and $B$. verbascifolia (Fig. 3 - first axis) is evidenced mostly due to the exclusive $C$. punctum, to $C$. achatina that has a clear preference for $B$. coccolobifolia (Andrade et al. 1996), and to $T$. melanocosta and $G$. exquisita that are associated with $B$. crassa and $B$. verbascifolia. The second axis shows $G$. indecora associated with $B$. crassa and the exclusive Anacampsis sp. associated with $B$. verbascifolia.

Some morphological traits of the hostplant species can be responsible for the pattern shown above. The key characteristic seems to be the presence of hairs on the leaf surface. Several works showed an association between hairy leaves and low attack by herbivores (see Southwood 1986 and included references). This tendency in Byrsonima is supported by the small number of caterpillars found on young leaves of $B$. crassa and $B$. verbascifolia (Table 2), which are quite

\section{TABLE 2}

Number of caterpillars found on young and mature leaves of three Byrsonima species between May 1993 and July 1994 at the University of Brasilia Experimental Farm, Brazil $\left(\chi^{2}=22.47, p<0.001\right)$
Host plant species

Byrsonima crassa

Byrsonima verbascifolia

Byrsonima coccolobifolia

\section{Young}

leaves

\section{5}

00
Mature

leaves hairy. G. exquisita and Anacampsis sp., which forage on mature leaves of these plants, also use the hairs for building shelters. G. exquisita construct very hard shelters and cover then with the host plant's hairs while Anacampsis sp. use the leaf trichomes to construct a soft tube. Shelters can provide favorable microhabitats for caterpillars (Capuccinno 1993) and this may be crucial for caterpillars under the dry conditions of the cerrado vegetation increasing the protection against desiccation (Diniz and Morais 1997).

Our study suggests that the morphological differences among Byrsonima species may markedly determine their associated herbivore community. This pattern is apparently linked to the herbivores' sheltering strategies (Diniz and Morais 1997). However, more studies evaluating the physiological and chemical characteristics of the plants are needed for a better understanding of the existing patterns. Further investigation on the mechanisms mediating such a high richness with low abundance per herbivore species is also needed for the cerrado vegetation.

\section{ACKNOWLEDGMENTS}

We thank V. O. Becker (University of Brasília) and K. S. Brown (University of Campinas) for identifying the lepidopteran species; P. S. Oliveira and T. M. Lewinsohn (University of Campinas) for their helpful comments on the manuscript; Jair Maia for his help on some figures (University of Brasília). We also thank C. Dias, N. Menezes and J. Silva for their field and laboratory assistance. Brazilian Research Council (CNPq) and FAPESP supported I. Andrade, and C. van den Berg was supported by CAPES.

\section{RESUMEN}

Hicimos un registro cuantitativo de larvas de Lepidoptera que se alimentán de tres espécies de Byrsonima (Malpighiaceae) que ocurren en el Brasil Central: $B$. crassa Nied, $B$. verbascifolia $\mathrm{L}$. Rich and $B$. 
coccolobifolia (Spr.) Kunth. Nuestro principal objetivo fué estimar la abundancia y riqueza de orugas en cada una de las espécies de planta. Encontramos un patrón de baja abundancia y alta riqueza de espécies de orugas asociadas a las espécies de Byrsonima. Verificamos, todavía, que la similaridade entre la fauna de $B$. crassa y $B$. verbascifolia fué más alta que entre estas espécies y $B$. coccolobifolia. Una vez que se sabe que hojas con mayor cantidad de vellos pueden afectar la colonización y estratégias de forrageo de herbivoros, sugerimos que las diferencias en la comunidade de orugas asociadas a las distintas espécies de Byrsonima están relacionadas con los diferentes niveles de vellosidad apresentados por cada una de las espécies de plantas. Esta tendencia en Byrsonima es apoyada por el bajo número de orugas encontradas en hojas jóvenes de $B$. crassa y $B$. verbascifolia que tienen muchos pelos.

\section{REFERENCES}

Andrade, I., I. R. Diniz \& H. C. Morais. 1996. A lagarta de Cerconøta achatina: biologia e ocorrência em plantas hospedeiras do gênero Byrsonima (Malpighiaceae). Rev. Bras. Zool. 12: 735-741.

Cappuccino, N. 1993. Mutual use of leaf-shelters by lepidopteran larvae on paper birch. Ecol. Entomol. 18 287-292.

De Vries P. J. 1987. The butterflies of Costa Rica. Princenton University Press, New Jersey, 327 p.

Diniz, I. R. \& H. C. Morais. 1997. Lepidopteran caterpillar fauna of cerrado host plants. Biodiv. Conserv. 6: 817-836.

Fielding, C. A. \& J. C.Coulson. 1995. A test of the validity of insect food-plant and life history records: Lepidoptera on heather (Calluna vulgaris). Ecol. Entomol. 20:343-350.

Janzen, D. H. 1988. Ecological characterization of a Costa Rican Dry Forest caterpillar fauna. Biotropica 20: 120-135.

Lawton, J. H. 1982. Vacant niches and unsaturated communities: a comparison of bracken herbivores at sites on two continents. J. Anim. Ecol. 51: 573-595.

Leather, S. R. 1986. Insect species richness of the British Rosaceae: the importance of host range, plant architecture, age of establishment, taxonomic isolation and species-area relationships. J. Anim. Ecol. 55: 841-860.

Lewinsohn, T. M. 1991. Insects in flower heads of Asteraceae in southeast Brazil: a case study on trop- ical species richness, p. 525-560. In Price P. W, T. M. Lewinsohn, G. W. Fernandes \& W. W. Benson (eds.). Plant-animal interactions: evolutionary ecology in tropical and temperate regions. John Wiley \& Sons, New York.

Loyola, R. \& G. W. Fernandes. 1993. Herbivoria em Kielmeyera coriacea (Guttiferae): efeitos da idade da planta, desenvolvimento e aspectos qualitativos de folhas. Rev. Bras. Biol. 53: 295-304.

Marquis, R. J. 1991. Herbivore fauna of Piper (Piperaceae) in a Costa Rican Wet Forest: Diversity, specificity and impact. p. 179-205. In P. W. Price, T. M. Lewinsohn, G. W. Fernandes \& W. W. Benson (eds.). Plant-animal interactions: evolutionary ecology in tropical and temperate regions. John Wiley \& Sons, New York.

Marquis, R. J. \& H. E. Braker. 1994. Plant-herbivory interactions: diversity, specificity and impact, p. 261-281. In L. M. McDade, K. S. Bawa, H. A. Hespenheide \& G. S. Hartshorn (eds.). La Selva: ecology and natural history of a neotropical rain forest. The University of Chicago Press, Chicago.

Morais, H. C., I. R. Diniz \& L. C. Baumgarten. 1995. Padrões de produção de folhas e sua utilização por larvas de Lepidoptera em um Cerrado de Brasília, DF. Rev. Bras. Bot. 18:165-172.

Neuvonen, S. \& P. Niemelä. 1981. Species richness of macrolepidoptera on Finnish deciduous trees and shrubs. Oecologia 51: 364-370.

Price, P. W., I. R. Diniz, H. C. Morais \& E. S. A. Marques. 1995. The abundance of insect herbivore species in the tropics: the high local richness of rare species. Biotropica 27: 468-478.

Ratter \& Dargie. 1992. An analysis of the floristic composition of 26 cerrado areas in Brazil. Edinburgh J. Bot. 49: $235-250$.

Schluter, D. \& R. E. Ricklefs. 1993. Species diversity: an introduction to the problem, p. 1-10. In R. E. Ricklefs, \& D. Schluter (eds.). Species diversity in ecological communities: historical and geographical perspectives. The University of Chicago Press, Chicago.

Sowthwood, T. R. E., V. C. Moran \& C. E. J. Kennedy. 1982. The assessment of arboreal insect fauna: comparisons of knockdown sampling and faunal lists. Ecol. Entomol. 7: 331-340.

Southwood, T. R. E. 1986. Plant surfaces and insects - an overview, p. 1-22. In B. Juniper\& R. Sowthwood (eds.). Insects and the plant surface. Edward Amold, Bal timore. 